\title{
The Importance of Audit Firm Characteristics and the Drivers of Auditor Change in UK Listed Companies
}

\author{
Vivien Beattie and Stella Fearnley*
}

\begin{abstract}
This paper explores the importance of audit firm characteristics and the factors motivating auditor change based on questionnaire responses from 210 listed UK companies (a response rate of $70 \%$ ). Twenty-nine potentially desirable auditor characteristics are identified from the extant literature and their importance elicited. Exploratory factor analysis reduces these variables to eight uncorrelated underlying dimensions: reputation/quality; acceptability to third parties; value for money; ability to provide non-audit services; small audit firm; specialist industry knowledge: non-Big Six large audit firm; and geographical proximity. Insights into the nature of "the Big Six factor" emerge. Two thirds of companies had recently considered changing auditors; the main reasons cited being audit fee level, dissatisfaction with audit quality and changes in top management. Of those companies that considered change, $73 \%$ did not actually do so, the main reasons cited being fee reduction by the incumbent and avoidance of disruption. Thus audit fee levels are both a key precipitator of change and a key factor in retaining the status quo.
\end{abstract}

\section{Introduction}

Significant changes have occurred in the UK auditing environment during the last decade. The relaxation of ethical guidelines concerning advertising and solicitation, the introduction of auditor registration and monitoring and the economic recession have led to a relative shift in the cost and demand parameters of the audit services market and hence in competitive pressures. Observed behavioural changes by market participants include tendering, aggressive fee renegotiation and opinion shopping by auditees, and low-balling (i.e. predatory pricing), response to auditees' opinion shopping behaviour and merger activity by auditors.

Although it is difficult to make causal inferences, these changes have undoubtedly had an impact on the structure of the audit services market. Recent evidence concerning the UK listed company market indicates an increase in both seller concentration and the instability of client-auditor relationships (Beattie and Fearnley, 1994). Their study reports measures of seller concentration for the period 1987-1991 using a database of 2,079 fully listed and USM domestic companies. The increase in

*Vivien Beattie is a senior lecturer in accountancy in the Department of Accountancy and Finance. University of Stirling and an academic fellow of the Institute of Chartered Accountants in England and Wales. Stella Fearnley is a senior lecturer in accounting in the Department of Accounting and Management Science, University of Portsmouth. The authors gratefully acknowledge the financial support of the ICAEW. This paper has also greatly benefited from the helpful comments of two anonymous referees and the editor. Correspondence should be addressed to Dr Beattie, Department of Accountancy and Finance, University of Stirling, Stirling. FK9 4LA the eight-firm concentration ratio from 0.64 to 0.79 was partitioned into three categories: a 0.09 increase attributable to audit firm mergers, a 0.07 increase due to voluntary client-auditor realignments and a countervailing decrease of 0.01 due to the impact of market entrants. 'Thus both audit firm mergers and voluntary realignments were significant causes of the rise in concentration. At the 20-firm level, however, the overall increase from 0.83 to 0.9 resulted primarily from voluntary realignments.

Beattie and Fearnley (1994) also report that a total of 341 companies $(16.4 \%)$ voluntarily changed their auditors at least once during 1987-1991. Of these changes, $40 \%$ were classed as intra-audit tier changes and $60 \%$ as inter-audit tier changes, with the tiers being defined as the top eight firms, firms 9-20 and those below the top 20. Given the overall increase in seller concentration, it is not surprising that the top tier gained the largest number of clients.

This macro-level description of change within the market for audit services can, however, offer limited insight into the competitive pressures and processes that give rise to the observed change. The present study therefore builds on existing research by examining the importance of audit firm characteristics and the factors motivating auditor change at the micro-level.

The extant auditor choice literature encompasses both the auditor change decision and the auditor selection decision. It is generally agreed that no comprehensive, well-specified theory of either

\footnotetext{
'The concentration ratios quoted are based on number of
} clients. 
auditor change or selection currently exists, although empirical and theoretical research during the last 25 years has provided a theoretical framework within which such issues can be addressed.

To date, there has been no systematic empirical study of the auditor choice process in the UK. To our knowledge, existing empirical studies relate exclusively to the US, with the exception of an Australian study by Craswell (1988). Given the different environments (especially regulatory environments) that exist across countries, it is important to conduct auditor choice studies in different countries, and perform cross-country comparisons in order to gain new insights (Wallace, 1987). The purpose of this study is to contribute to the auditor choice literature by examining the influences on the auditor choice decision in a country where this decision has not been studied and following a period of rapid and significant environmental upheaval within the auditing profession (see above). A postal questionnaire survey of listed companies is used to elicit information concerning the importance of audit firm characteristics and factors that influence the auditor change decision. A random sample of 300 companies was surveyed, resulting in 210 usable replies, which represents a $70 \%$ response rate.

A factor analysis of 29 potentially desirable audit firm characteristics reveals a number of common underlying dimensions of importance to companies. The extent to which companies consider changing auditors, the main reasons for this and the reasons for not subsequently changing auditors are also explored.

The remainder of this paper is structured as follows. Section two reviews the extant auditor choice literature, which forms the basis of the content of the research instrument. Section three outlines the sample and data collection procedures employed. The results, together with discussion, are presented in the fourth section. The final section summarises and concludes.

\section{Auditor choice literature}

In conceptualising the auditor choice process it is important to recognise that auditor choice emerges from the client's characteristics, potential auditors' characteristics and the auditing environment. A significant change in one (or more) of these three areas is required for a client to decide to change their auditor, since the costs of switching are material. ${ }^{2}$ The auditor change process is usefully separated into two stages, as suggested by Francis and Wilson (1988, p.668), since the reasons for displacement of the former auditor might be unrelated to the specific choice criteria used in selecting

'DeAngelo (1981b, p. 188) cites the low rate at which firms change auditors as evidence of significant switching costs. the new auditor. Companies first decide to change auditors and then make a reselection. Auditor displacement may be motivated by a change in company circumstances (i.e. by factors unconnected with the current audit firm's performance) such as a change in top management or by specific problems and disagreements. The reasons for change are, therefore, not necessarily related to generic audit firm characteristics and also not necessarily involved in the choice of a new auditor. Although there exists a common set of factors underlying change and choice decisions, both decisions also have unique factors.

The demand for audit services in free and regulated markets was examined by Wallace (1980). Three separate but interlinked sources of demand are identified: agency (or stewardship) demand, information demand and insurance demand. Agency theory, as developed by Jensen and Meckling (1976), indicates that the bonding role of an audit can reduce agency costs arising from the self-interested behaviour of agents. The existence of differential agency costs across clients and over time therefore results in a heterogeneous demand for audit services, characterised by DeAngelo (1981a, b) as different levels of audit quality.

The information demand for audit, originally explored by Dopuch and Simunic (1980 and 1982), is closely related to the agency demand, since it also arises from information asymmetries. The selection of credible auditors not only signals management's honesty and quality to all interested parties, but also reduces agency costs via the monitoring function. The arguments of both DeAngelo and Dopuch and Simunic are often referred to as the 'product differentiation hypothesis'. More recent analytical studies have employed the information/ signalling framework to explore the implications of auditor choice (Bar-Yosef and Livnat, 1984; Titman and Trueman, 1986; and Dye, 1991). The insurance dimension of an audit forms the basis of the third source of demand. It is argued that the audit serves to indemnify investors and creditors against financial losses via the auditor's professional liability exposure.

Each of these three sources of audit demand generates a rank ordering of auditors. DeAngelo (1981b) argues that auditor size serves as a surrogate for audit quality, since larger firms have reduced incentives to lower audit quality opportunistically in order to retain any single client. Dopuch and Simunic (1980 and 1982) infer that credibility is associated with an auditor's reputation or brand name, based on the observed dominance of large

${ }^{3}$ It has since been recognised that industry-specific reputation is an important alternative basis for rating audit firm credibility (Simunic and Stein, 1986, p. 71 ).

${ }^{4}$ Both credibility and reputation refer to perceiced audit quality, since audit quality per se is unobservable (or at least extremely costly to evaluate). 
audit firms in the market for publicly-held company auditors. ${ }^{3.4}$ Finally, a number of writers argue that larger audit firms have 'deeper pockets' than smaller firms due to their higher level of insurance.

This consideration of demand-side factors suggests a number of client characteristics that will affect the type of audit firm selected, in terms of its quality and credibility. These characteristics centre on agency-related variables, such as size, level of gearing and management share ownership. These factors will determine the general size, class and/or industry specialisation of the audit firm selected. The specific audit firm chosen is also influenced by supply-side factors, i.e. auditor characteristics. In particular, audit firm specialisation in audit technologies can be expected to yield economies of both scale and scope. ${ }^{5}$

Additional auditor characteristics of relevance relate to the audit team, rather than the firm generally, and reflect the quality of working relationships. Other relevant client or auditor characteristics include the existence of significant foreign operations (Eichenseher, 1985), the existence of interlocking directorates between client companies (Davison et al., 1984), the association between client and auditor structures (Kaplan et al., 1990) and the geographical proximity of the auditor (Stokes, 1992). Based on these arguments, clientauditor alignments can be viewed as the minimum cost match between client needs and auditor services. A significant change in either the client or auditor's characteristics can therefore induce a realignment if the other party is either unable or unwilling to accommodate it.

Early empirical studies collected management's declared reasons for actual auditor changes using open-ended questionnaires (Burton and Roberts, 1967; Carpenter and Strawser, 1971; Bedingfield and Loeb, 1974; and Eichenseher and Shields, 1983). The most frequently cited reasons for change were changes in top management, need for additional services/dissatisfaction with services offered, audit fee too high, need for new financing, takeover by another company, poor working relationships and technical disagreements.

Statistical studies have examined the association between either (i) specific client or auditor characteristics and observed auditor choices, or (ii) changes in these characteristics and observed auditor changes. Firth and Smith (1992) find that the selection of a Big Eight audit firm (a brand name proxy for audit quality) is associated with agency cost variables and the need for signalling. The propensity to change auditors has been found to be positively related to disagreements (DeAngelo,

${ }^{3}$ Scale economies permit firms to offer competitive fees while scope economies, which result from knowledge spillovers, facilitate the provision of sophisticated audit services in addition to a range of non-audit services.
1982), financial distress (Schwartz and Menon, 1985), initial public offerings (Menon and Williams, 1991), the early and late stages of the auditor-client relationship (Levinthal and Fichman, 1988), and receipt of a qualified audit opinion (Chow and Rice, 1982; Craswell, 1988; and Citron and Taffler, 1992) (although this latter finding is not supported by Schwartz and Menon, 1985). ${ }^{6}$ The propensity to change auditors has, however, been found not to be related to the level of non-audit services purchased (De Berg et al., 1991).

In more recent multivariate studies, Williams (1988) finds that the propensity to change auditors is negatively related to the incumbent's industry specialisation and tenure and positively related to the receipt of adverse media publicity by the client company. Using panel data, Lindahl (1992) finds that client company financial distress, size and mergers, and the market share and size of the auditor are all associated with auditor changes. Haskins and Williams (1990) focus on intra-Big Eight auditor changes, finding that the most important factors associated with such changes are client financial distress, size and growth, together with audit firm fee levels and industry dominance.

Johnson and Lys (1990) report that the direction of auditor change, in terms of relative audit firm size (a proxy for differences in audit firm cost structures), can generally be attributed to changes in client characteristics that influence supplier costs (expansion, financing, profitability and audit risk). Francis and Wilson (1988) find that, after controlling for client size and growth, changes to/from a Big Eight firm are associated with agency cost variables. Healy and Lys (1986) find that companies audited by a non-Big Eight firm are more likely to retain a Big Eight acquirer following an audit firm merger if they benefit from the Big Eight firm's specialised services and/or reputation.

Studies have also examined several consequences of auditor change. Companies that change auditors following receipt of a qualified opinion have been shown in some studies to receive 'improved' opinions (Craswell, 1988), whereas other studies show no such shift (Chow and Rice, 1982 and Smith, 1986). DeBerg et al. (1991) find evidence that the level of non-audit services purchased declines following auditor change. Studies have shown generally negative overall share price reactions to auditor changes, although in most cases there are no systematic abnormal returns (Fried and Schiff, 1981; Nichols and Smith, 1983; Smith, 1988; and Johnson and Lys, 1990).

\footnotetext{
${ }^{6} \mathrm{~K}$ rishnan (1992) distinguishes 'internal' opinion shopping, where incumbent auditors and companies negotiate to reach a mutually acceptable opinion, from 'external' opinion shopping (a substitute behaviour), where companies search for more accommodating auditors. He finds that auditor changers, as failed internal opinion shoppers, face stricter standards than non-changers in the year prior to change.
} 
There is, however, evidence that auditor changes associated with disagreements, qualified audit opinions and changes away from Big Eight auditors result in statistically significant negative price movements, especially at high levels of management ownership (Smith, 1988; Eichenseher et al., 1989; and Albrecht and Lamy, 1992). With regard to audit fee cutting following change, Francis (1984) finds no evidence of this whereas Simon and Francis (1988) and Ettredge and Greenberg (1992) find an average discount in the initial year of $24 \%$ and $25 \%$ respectively. ${ }^{?}$

\section{Methods}

Sample Selection and Construction of Mailing List

The sample is drawn from the population of domestic officially listed and USM companies in the UK and Ireland as at 30 April 1992. An alphabetical listing of company names was obtained from Extel Financial Ltd. This data set also contained addresses and the name of either the finance director or (in the absence of this) the company secretary. A systematic sample of 300 was selected from this list, i.e. every seventh company.

\section{Research Materials and Questionnaire Administra- tion Procedures}

The questionnaire used closed-form questions and contained six sections. The first section contained general questions, while the second section elicited the importance of 29 audit firm characteristics using a five-point Likert-type scale with verbal anchors. Questions in the second section are framed as a generic task, in that no specific reference is made to the company's current audit firm. The third section identified those companies which had considered making a voluntary change in auditors during the past five years, elicited how seriously this change had been considered and asked the respondent to indicate which of 26 reasons caused a change to be considered. The remainder of the questionnaire forms part of a separate paper. The draft questionnaire was pretested with the assistance of several senior business executives and audit partners and the content, ordering and terminology was revised accordingly.

The reasons offered for considering an auditor change resulted from an analysis of the declared reasons for change cited in prior questionnaire studies and hypothesised variables from statistical auditor change studies, with 26 distinct themes being identified. The 29 auditor characteristics

\footnotetext{
${ }^{7}$ Simon and Francis (1988) found that this fee discount in the initial year persisted, at reduced levels, for approximately two years, and appeared to result partly from 'low balling'. Ettredge and Greenberg (1992) found that the size of fee discounts in the initial year was associated with changes in audit quality and technological efficiency and the number of auditors bidding on the engagement.
}

whose importance was rated by respondents were derived by extracting relevant themes from the potential change drivers (rewording as necessary) and from a review of the auditor choice literature. Several additional characteristics were added during piloting.

The questionnaire was accompanied by an explanatory covering letter which assured the confidentiality of responses. A return envelope was also provided. The questionnaires were serially numbered to permit non-respondents to be followed up. A reminder letter was sent out after 10 days, with a second request (accompanied by a duplicate copy of the questionnaire and the original covering letter) being sent after a further 10 days.

\section{Results}

\section{Response Rate and Tests for Bias}

From the total sample of 300,225 responses were received. Fifteen responses were not usable for a variety of reasons, leaving 210 usable replies, representing a response rate of $70 \%{ }^{8}$ This rate compares very favourably with those obtained in recent UK studies covering similar populations of companies and respondents.

A number of tests for response bias were performed. First, responding and non-responding companies were compared on the basis of size (measured as total assets) using the WilcoxonMann-Whitney non-parametric test. The hypothesis that the two groups have been drawn from the same population was not rejected $(\alpha=0.05)$. This comparison was also applied to early (first 70) and late (last 70) responders, on the assumption that late responders are similar to non-responders (Oppenheim, 1966, p. 34). Again, the null hypothesis of no difference was not rejected $(\alpha=0.05) .^{9}$ Finally, the companies were formed into four broad industrial groupings based on Stock Exchange groups (capital goods, consumer goods, other and financial). A chi-squared test indicated an association between industry and response/non-response $(\alpha=0.01)$. The percentage of responders was highest among the 'other' group (86\%) and lowest among the financial group $(61 \%)$. Despite the limitations of such tests (discussed by Wallace and Mellor, 1988), given the high response rate obtained, we conclude that response bias is not a serious threat to the validity of our results. Table 1

\footnotetext{
${ }^{8}$ Five companies indicated that they did not wish to participate due to lack of management time, four said that their company policy was not to participate in questionnaires of this nature, three said that their auditor choice was in the hands of a parent company or comparable to another company in the sample, two said that the addressee had left the company and one company was in voluntary liquidation.

${ }^{9}$ Further tests for response bias comparing early and late responders were not conducted since the questionnaire did not contain suitable key summary variables.
} 
Table 1

Analysis of Respondents by Company Size and Industry Group

$\begin{array}{lrrc}\text { Size group } & \begin{array}{c}\text { Total assets } \\ (\mathrm{fm})\end{array} & \text { No. } & \% \\ \text { Small } & <20 & 74 & 35.9 \\ \text { Medium } & 20-100 & 80 & 38.8 \\ \text { Large } & \geqslant 100 & \underline{52} & \underline{\underline{25.3}} \\ & & \underline{100.0}\end{array}$

*Data on four newly listed companies were not available.

\begin{tabular}{|c|c|c|c|}
\hline Industry group & $\begin{array}{l}\text { Response } \\
\text { rate }\end{array}$ & No. & $\%$ \\
\hline Capital goods & $74 \%$ & 70 & 33.3 \\
\hline Consumer goods & $63 \%$ & 48 & 22.9 \\
\hline $\begin{array}{l}\text { Other (including } \\
\text { three oil and gas } \\
\text { companies) }\end{array}$ & $61 \%$ & 50 & 23.8 \\
\hline Financial & $86 \%$ & $\frac{42}{210}$ & $\frac{20.0}{100.0}$ \\
\hline
\end{tabular}

provides an analysis of the respondents by size and industry.

A further factor that can affect the validity of questionnaire responses is the suitability of individual respondents, who should be both knowledgeable about the relevant practices, and involved in the relevant decisions at a senior level. Based on title, the respondents were: finance director $(58 \%)$, company secretary $(12 \%)$, financial controller $(9 \%)$, director $(6 \%)$, accountant $(5 \%)$, chief accountant $(3 \%)$ and other/not stated $(7 \%)$. It is clear that nearly all respondents are senior executives who would be intimately involved in the auditor choice decision. ${ }^{10}$ The risk of uninformed respondent bias is therefore minimal.

\section{Audit Firm Characteristics}

Section two of the questionnaire asked respondents to indicate the importance to their company of each of 29 audit firm characteristics, using a scale of 1 to 5 . The questions did not relate specifically to the company's current audit firm, rather they were set in a generic context. The results are summarised in Table 2. Over the group as a whole, the three most important characteristics to emerge were: (i) integrity of firm; (ii) technical competence of firm; and (iii) quality of working relationship with audit partner(s). When each individual respondent was asked to identify the three most important characteristics to them, technical competence of firm service was most frequently cited over the three slots $(n=86)$, followed by value for money of audit

\footnotetext{
${ }^{10}$ The questionnaire revealed that it is the finance director who is most frequently responsible for negotiating the audit fee with the auditors and who is most influential in the appointment process (detailed results not reported here).
}

$(\mathrm{n}=84)$ and quality of working relationship with audit partner $(n=59)$ (see Table 3 ). Interestingly, Big Six audit firm was cited by 40 companies as a top three characteristic, despite the fact that it ranked only 20 th for the group of respondents as a whole.

Clearly there exist significant within-group variations in preferences with respect to audit firm characteristics. We investigated the extent to which company size or industry group could explain these differences. First, we classified the 210 respondents as small or large based on the median level of total assets. Using a two-tailed t-test, statistically significant differences (at the $10 \%$ level) between the two groups in terms of their responses to the 29 characteristics in Table 2 emerged for 11 characteristics (see third-last column of Table 2). Ten of these characteristics were rated as of significantly more importance by large companies: technical competence of audit partner; ethical standards of audit partner; technical competence of audit engagement staff; audit quality; willingness to offer guidance on accounting principles; quality of advice to management; Big Six audit firm; acceptability to company's regulators; specialist knowledge of your industry; and existence of offices located close to principal accounting functions. One characteristic was rated as of significantly less importance by large companies: low absolute level of audit fee.

Second, we classified the 210 respondents into four broad industrial groupings based on Stock Exchange groups (capital goods, consumer goods, financial and other) and conducted a KruskalWallis test to determine whether any statistically significant differences existed among the four groups (Siegel and Castellan, 1988, pp. 206-212). Significant differences (at the $10 \%$ level) emerged for seven of the 29 characteristics: quality of working relationships with audit partner; willingness to offer guidance on accounting principles; same audit firm as other group companies; willingness to provide detailed cost information; specialist knowledge of your industry; existence of offices located close to principal accounting functions; and a local audit firm (see second-last column of Table 2). The first four of these characteristics were most important to capital goods companies, the fifth and seventh to financial companies and the sixth to consumer goods companies.

Subsequent multiple comparison procedures based on Tukey's studentised range test (SAS, 1990, ch. 13) revealed, however, that in the case of the second, sixth and seventh characteristics listed above, no pairwise comparisons were significant at the $5 \%$ level. ${ }^{11}$ Capital goods companies rated the

\footnotetext{
"This lack of any significant pairwise differences is not unusual, since the Tukey test is conservative in that it controls the type 1 experimentwise error rate.
} 


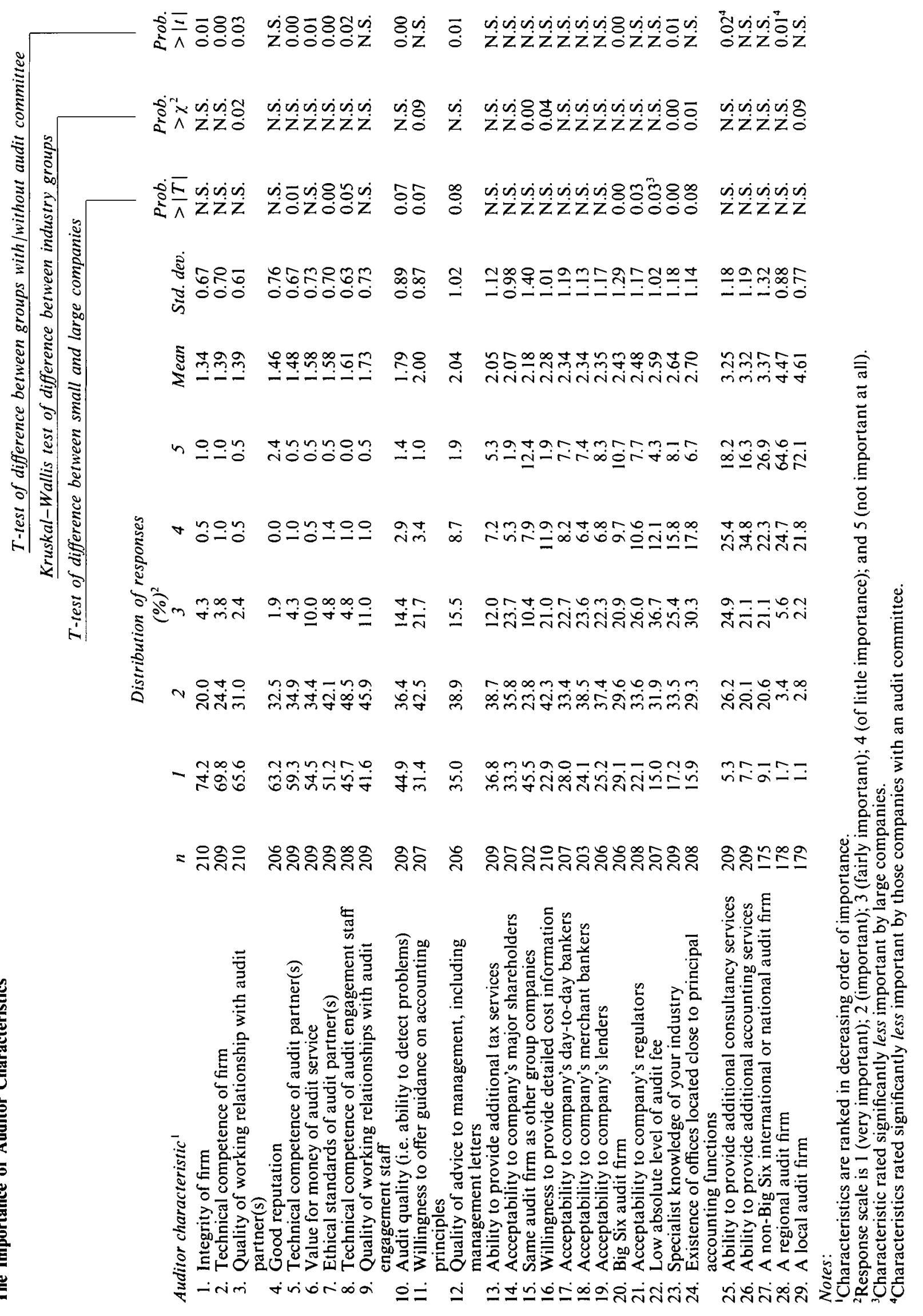


Table 3

The Three Most Important Auditor Characteristics

\section{Auditor characteristic}

1. Technical competence of firm

2. Value for money of audit service

3. Quality of working relationship with audit partner(s)

4. Integrity of firm

5. Big Six audit firm

\begin{tabular}{ccc} 
& \multicolumn{2}{c}{ Individual ranking frequency } \\
Most & 2nd most & 3rd most \\
important & important & important \\
$38^{1}$ & $29^{1}$ & $19^{3}$ \\
$20^{3=}$ & $24^{2}$ & $40^{1}$ \\
$18^{6}$ & $16^{4}$ & $25^{2}$ \\
& & \\
$20^{3=}$ & $20^{3}$ & $18^{4}$ \\
$26^{2}$ & $8^{9=}$ & $5^{13=}$
\end{tabular}

Group rank (from Table 2)

2

6

3

1

20

Notes:

*Superscripts indicate the rank of characteristics within each top three slot (thus, for example, 18 respondents cited 'quality of working relationship with audit partner(s)' as the most important auditor characteristic and this was the sixth most frequently cited such reason).

${ }^{\ddagger}$ Auditor characteristics are shown in decreasing frequency of total citations across the three top slots.

quality of working relationship with audit partner and common group auditor of significantly more importance than financial companies, and willingness to provide detailed cost information of more importance than consumer goods companies. Financial companies rated specialist industry knowledge of more importance than the other three industrial groups.

Since $41 \%$ of the respondents had audit committees, we investigated whether this feature influenced the importance attributed to auditor characteristics. The final column of Table 2 reports the two-tailed significance level of a t-test between the two groups. Significant differences (at the $5 \%$ level) emerged for 13 of the 29 characteristics. With the exception of 'ability to provide additional consultancy services' and 'a regional audit firm', these characteristics were rated of more importance by companies with an audit committee.

It is to be expected that many of the 29 audit firm characteristics will be highly correlated. An exploratory factor analysis was performed using the principal components method with varimax rotation in an attempt to uncover the critical underlying dimensions. Eight initial factors were extracted, based on the eigenvalue $\geqslant 1$ criterion (Kim and Mueller, 1978, p. 49). These factors explained $64 \%$ of the variance among the audit firm characteristics.

Table 4 summarises these eight factors, providing a subjective factor label based on each factor's constituent auditor characteristics. Those constituent characteristics with factor loadings greater than $|0.50|$ (i.e. 25 out of 29) are also shown, together with their factor loadings. This analysis reveals the importance of auditors' acceptability to third parties and ability to provide non-audit services (factors two and four respectively), which are auditor characteristics not rating highly in Table 2 . It is interesting to note that the auditor characteristic of being a Big Six firm does not emerge from the factor analysis. In fact this characteristic appears to be multidimensional, being positively associated with factors $1,2,6$ and 8 , and negatively associated with factor 5 (the relevant factor loadings are $0.24,0.28,0.36,0.37$ and -0.29 respectively). This finding provides empirical support for the arguments that these firms enjoy a reputation that makes them more acceptable to third parties, that they are more likely to possess specialist industry knowledge and be located nearby. There are clearly, however, a significant number of companies which reject such firms in favour of either small audit firms (factor 5) or larger, non-Big Six audit firms (factor 7). Nor does the eighth-ranked auditor characteristic 'technical competence of audit engagement staff' appear in the factor analysis. This characteristic is two-dimensional, with positive loadings of 0.48 on factor 1 and 0.46 on factor 3 .

It is noticeable from Tables 2 and 4 that there are several auditor characteristics that are not ranked of high importance, but which nevertheless load on factors. In particular, factor 2 (acceptability to third parties) comprises five related characteristics ranked $14,17,18,19$ and 21 . This result can be attributed to the existence of five questions which clearly relate to the same dimension. While most respondents were concerned about the auditor's acceptability to a specific third party, there were very few concerned about more than one group (this is apparent from the high standard deviation in Table 2). Thus the average importance of each characteristic was low. In addition, factors 4-8 include characteristics of middle and low importance. There is, in fact, a distinct drop between factors $1-3$ and $4-8$ in the proportion of variance explained by these factors.

\section{Auditor Change Consideration}

Section three of the questionnaire asked our 210 respondents to indicate how seriously they 
吾

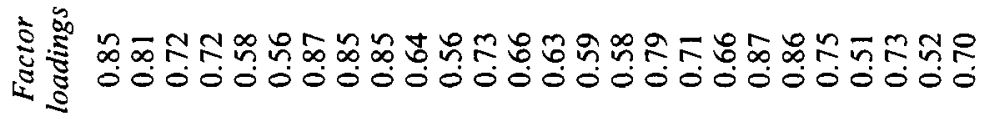
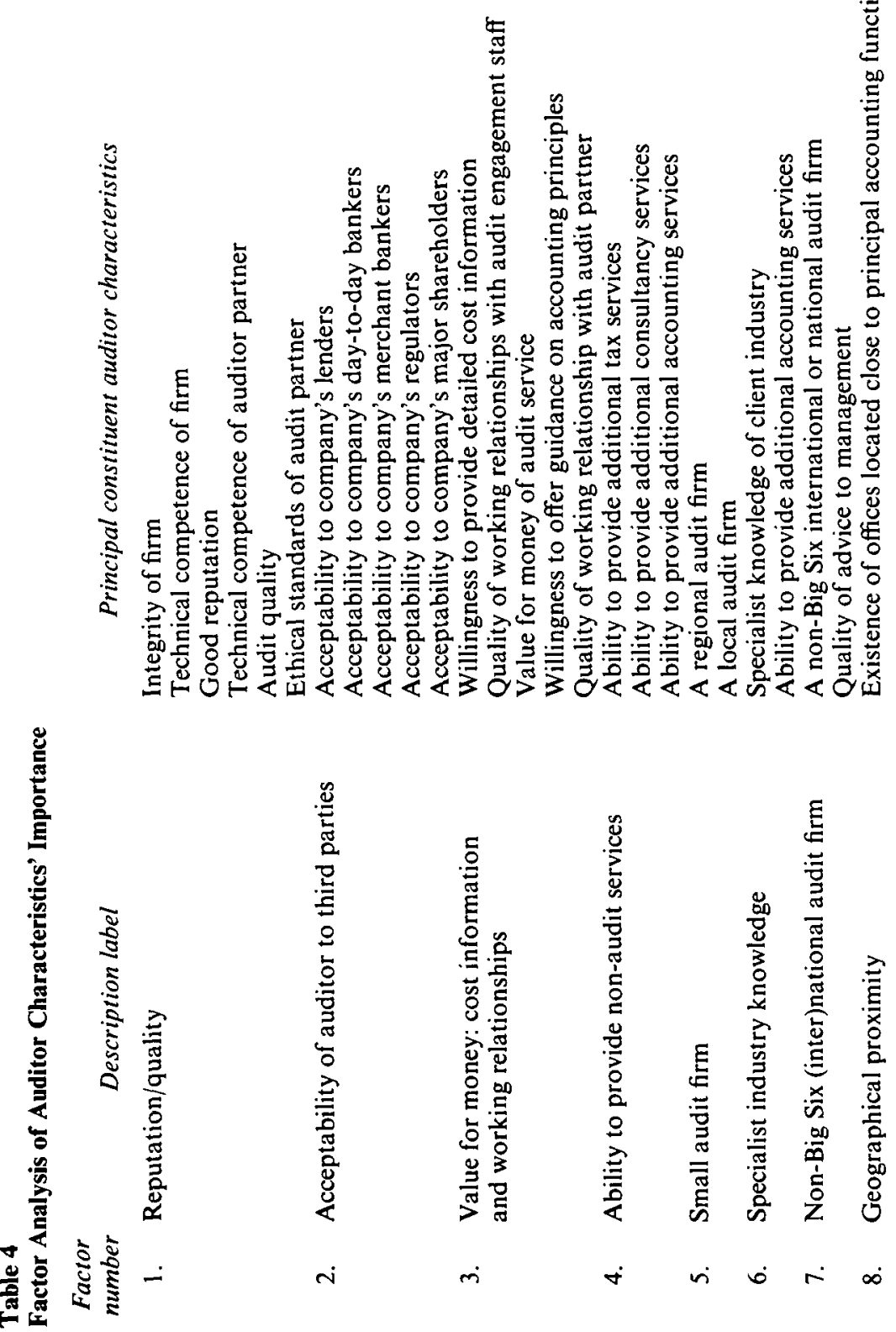


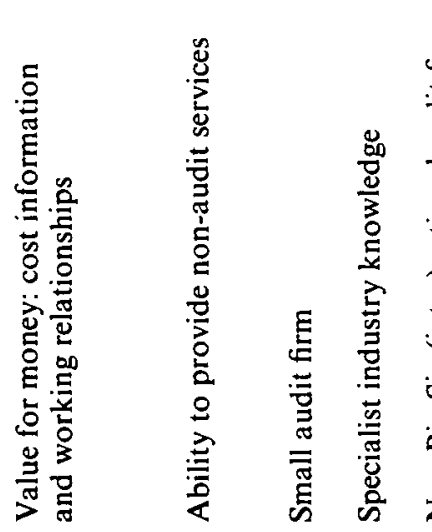

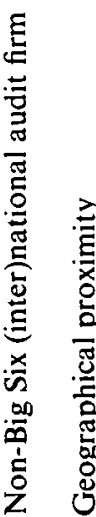

vi

$\infty$ 
Table 5

Stated Reasons for Consideration of a Change in Auditor

\section{Reason*}

\begin{tabular}{|c|c|}
\hline $\begin{array}{l}\text { Number of } \\
\text { companies }\end{array}$ & $\begin{array}{c}\% \\
(n=139)\end{array}$ \\
\hline 92 & 66 \\
\hline 46 & 33 \\
\hline 34 & 25 \\
\hline 25 & 18 \\
\hline 24 & 17 \\
\hline 22 & 16 \\
\hline 20 & 14 \\
\hline 20 & 14 \\
\hline 19 & 14 \\
\hline 19 & 14 \\
\hline 18 & 13 \\
\hline 17 & 12 \\
\hline 15 & 11 \\
\hline 15 & 11 \\
\hline 12 & 9 \\
\hline 12 & 9 \\
\hline 10 & 7 \\
\hline 10 & 7 \\
\hline 7 & 5 \\
\hline 7 & 5 \\
\hline 6 & 4 \\
\hline 5 & 4 \\
\hline 4 & 3 \\
\hline 4 & 3 \\
\hline 3 & 2 \\
\hline 1 & 1 \\
\hline
\end{tabular}

1. Level of audit fee

2. Dissatisfaction with audit quality (i.e. auditor's ability to detect problems)

3. Changes in company's top management

4. Company growth required increased technical capacity from audit firm

5. Need for group auditor rationalisation

6. High turnover of audit engagement staff

$7=$. Merger/takeover with/by another company

$7=$. Need for additional services

$9=$. Audit firm merger

$9=$. Use of inexperienced audit engagement staff

11. Need for Big Six audit firm

12. Personality clashes with audit partner/staff

$13=$. Change in audit partner

$13=$. Poor working relationships with audit partner/staff

$15=$. Need for multinational audit firm with foreign offices in same geographical areas as client's operations

$15=$. Disagreements over accounting principles

$17=$. Influence of merchant bankers/underwriter

$17=$. Inaccessibility of audit partner

$19=$. Influence of actual or potential equity or loan providers

$19=$. Need for audit firm specialising (or not) in client's industry

21. Need for national, rather than local, audit firm

22. Disagreement with audit opinion

$23=$. Influence of regulators

$23=$. Need for audit firm with local domestic office

25. Influence of company's day-to-day bankers

26. Need for local, rather than national, audit firm

* Reasons are shown in decreasing frequency of citation.

had considered changing their auditors in the past five years, and the reasons for this (selected from a list of 26 potential reasons). Only $34 \%$ had not considered changing their auditors at all, while $24 \%$ had considered the matter very seriously, $11 \%$ seriously, $10 \%$ fairly seriously and $21 \%$ casually. Table 5 provides a complete breakdown of all the stated reasons cited as contributing to the consideration of a change in auditor. It should be recognised that a number of the reasons cited overlap to some extent. For example, "use of inexperienced audit engagement staff' (item ranked ninth equal) may contribute to an overall 'dissatisfaction with audit quality' (item ranked second). The 139 companies cited a total of 467 reasons, an average of 3.3 contributory reasons each.

The two most common reasons cited related to problems with the audit per se and were the level of audit fee $(66 \%)$ and dissatisfaction with audit quality (defined as the auditor's ability to detect problems) $(33 \%)$. Eighteen other reasons were, however, cited by a significant (i.e. $\geqslant 5 \%$ ) percentage of companies. Of these reasons, five related to problems with the quality of the relationship with the audit team (high turnover of audit engagement staff, use of inexperienced audit engagement staff, personality clashes with audit partner/staff, poor working relationships with audit partner/staff and inaccessibility of audit partner), eight related to structural changes at the auditee, (top management changes, growth, auditor rationalisation, merger, and need for additional services, Big Six firm, multinational firm or industry specialist), two related to changes concerning the audit firm (audit firm merger and change in audit partner), two related to third party influences (merchant banker/underwriter and capital providers) and one concerned disagreements over accounting principles.

Of the 56 companies that had undergone an in voluntary change in auditor due to an audit firm merger (not shown in Table), $19(33 \%)$ cited this as a contributory reason for considering further change. It may be noted, given the recent Cadbury Report (1992) recommendations on the rotation of audit partners, that $11 \%$ of respondents cited this as a reason for considering an auditor change. Disagreements concerning accounting principles were cited by $9 \%$ of companies as a reason for considering auditor change, with $4 \%$ citing disagreement with the audit opinion. This is suggestive that auditor changes may in some cases arise from 'opinion shopping'. 
We again segmented the respondents into those with/without an audit committee. Based on chisquared tests, there was no significant association (at the 5\% level) between any of the top five stated reasons for considering change and the existence of an audit committee.

Also using a chi-squared test, we investigated whether the stated reasons for consideration of auditor change were associated with the seriousness with which change was considered. To avoid low cell frequencies, adjacent categories were combined to form a 'more serious' group $(n=73)$ and a 'less serious' group $(n=66)$. Four reasons were cited significantly more frequently (at the $5 \%$ level) by the more serious group: dissatisfaction with audit quality $(p=0.001)$; company growth $(p=0.002)$; auditor rationalisation $(p=0.048)$; and need for Big Six firm $(p=0.001)$. These issues relate primarily to structural changes at the auditee. Interestingly, however, the most frequently cited reason overall (level of audit fee) showed no statistically significant difference.

When asked to rank the three most important reasons for considering an auditor change, a similar pattern of responses to that in Table 5 emerged, as can be seen from Table 6 .

Clearly there will, in many cases, exist a relationship between the desirability of audit firm characteristics and change drivers, since if a company is considering a change of auditor, then this may indicate that its current auditor is not satisfactory with respect to a characteristic which is rated important (although there can be other reasons, e.g. an auditor rationalisation policy). We therefore investigated the consistency of the relationship between the three most important change drivers and the desirability of audit firm characteristics. We hypothesised that the 45 respondents who cited 'level of audit fee' as the most important reason for considering auditor change would rate 'low absolute level of audit fee' as a more important audit firm characteristic than the other respondents who had considered change. Based on a t-test, a statistically significant difference in the expected direction did exist between the two groups $(t=1.79$, $\mathrm{p}=0.038$, one-tailed).

Similarly, we hypothesised that the 24 respondents who cited 'dissatisfaction with audit quality' as the second most important reason for considering auditor change would rate 'audit quality' as a more important characteristic than the others. In this case, although the difference between the two groups was in the expected direction, it was not statistically significant $(t=1.08, p=0.144)$. The third most important reason for considering auditor change, 'changes in company's top management', has no related auditor characteristic.

Of the 139 companies that had considered changing their auditors, $37(27 \%)$ did actually effect a change while $102(73 \%)$ did not. The reasons given by the non-changers are summarised in Table 7. Fee reduction by the incumbent auditor was most frequently cited, either singly or in combination with other factors. The most common single reason

\section{Table 6}

The Three Most Important Stated Reasons for Considering Auditor Change

\section{Stated reason}

1. Level of audit fee

2. Dissatisfaction with audit quality (i.e. auditor's ability to detect problems)

3. Changes in company's top management

4. High turnover of audit engagement staff

5. Need for group auditor rationalisation

6. Merger/takeover with/by another company

7. Use of inexperienced audit engagement staff

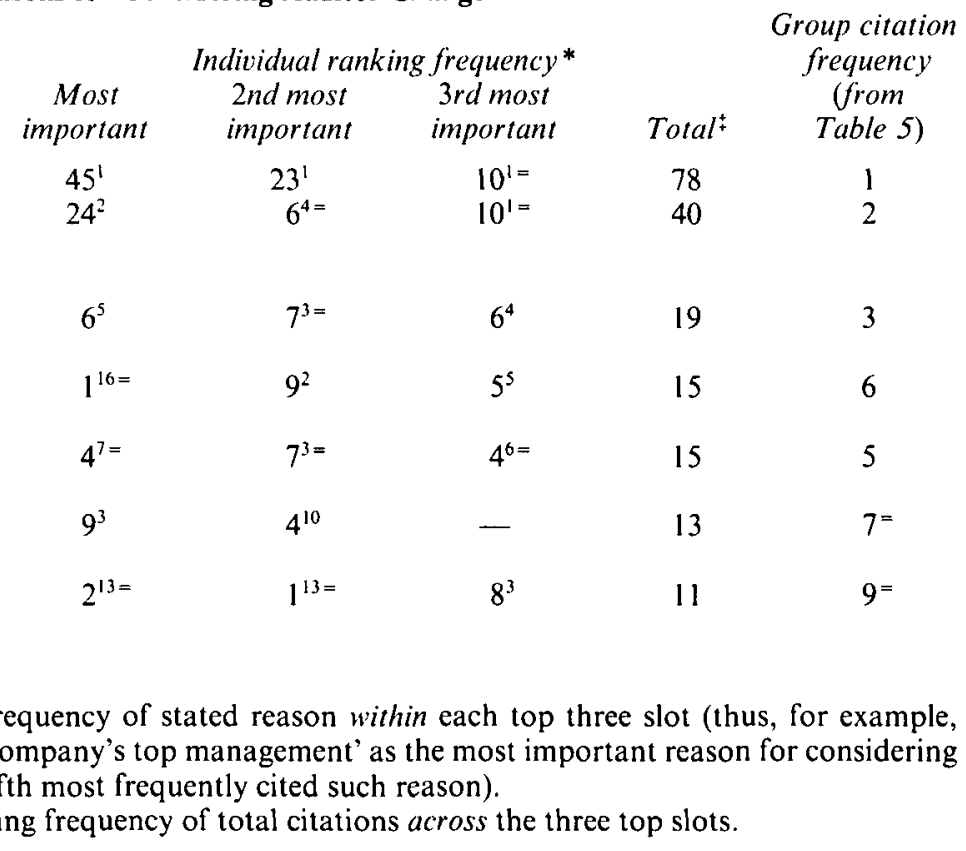

Notes:

*Superscripts indicate the citation frequency of stated reason within each top three slot (thus, for example, six respondents cited 'changes in company's top management' as the most important reason for considering auditor change and this was the fifth most frequently cited such reason).

stated reasons are shown in decreasing frequency of total citations across the three top slots. 
Table 7

Reasons for Not Changing Auditors Following Consideration of Change

$\begin{array}{cccc}\text { Sole } & \text { Number of companies } \\ \text { reason } & \text { Contributory } & \begin{array}{c}\text { Combined } \\ \text { frequency }\end{array} & \% \\ \text { cited } & \text { reason } & \text { of citation } & (n=102) \\ 19 & 23 & 42 & 41 \\ 26 & 13 & 39 & 38 \\ 14 & 14 & 28 & 27 \\ 3 & - & 3 & 3 \\ 13 & 7 & 20 & 20\end{array}$

1. Incumbent auditor offered reduced audit fee

2. Avoidance of disruption and loss of management time

3. Incumbent auditor offered improved quality of service

4. Change of audit partner

5. 'Other'

13

Note: Reasons are shown in descending frequency of combined frequency of citation.

given was, however, avoidance of disruption and loss of management time. Three respondents mentioned change of audit partner as the single reason for not proceeding with the change. 'Other' reasons included inertia (four cases), decision pending (three cases), satisfaction with incumbent auditors (three cases), lack of suitable alternatives in the area (one case), advice from merchant bank (one case) and new shareholder did not insist (one case).

We examined the association between the top three most important stated reasons for considering auditor change and the main sole reasons for not subsequently changing auditors. Where level of audit fee prompted auditor change consideration, $50 \%$ did not change because the incumbent offered a reduced audit fee, $35 \%$ did not change to avoid disruption and loss of management time and $15 \%$ did not change because the incumbent offered an improved quality of service. The corresponding figures for dissatisfaction with audit quality and changes in company's top management were $12 \%$, $44 \%, 44 \%$ and $25 \%, 25 \%, 50 \%$ respectively.

\section{Discussion}

The auditor choice process is clearly a complex one. Not only does it involve multi-attribute decision analysis, on the part of one or more individuals, but these attributes are constantly changing within a dynamic decision setting. Despite this, our analysis of 29 potentially desirable audit firm characteristics does reveal eight uncorrelated underlying dimensions: reputation/quality; acceptability to third parties; value for money; ability to provide non-audit services; small audit firm; specialist industry knowledge; non-Big Six large audit firm; and geographical proximity. These findings are generally consistent with the findings of Lynn (1987) in the US and of a recent UK survey (Fitzgerald, 1992). The UK survey was restricted to the consideration of six auditor characteristics and covered businesses of all sizes, although no precise sampling details are reported. Regular partner contact was ranked most important while the lowest competitive price was ranked least important.
Given the current debate concerning audit fee competition, an interesting finding to emerge from the present study is that, although value for money is ranked as the sixth most important audit firm characteristic in general, the low absolute level of audit fee is ranked only 22nd (see Table 2). In contrast, fee level is the most frequently cited reason for consideration of a change in auditor. Fee reduction by incumbent auditors was also the most frequently cited reason for not changing auditors. There are two possible explanations of this result. First, it should be noted that the value for money concept has two dimensions-price and quality. During piloting, value for money was a concept suggested to us several times as an important auditor characteristic, however it was not suggested to us as a change driver. It would appear that when considering change, auditees think in terms of price or quality, rather than their joint effect. We therefore maintained this perceptual distinction in the questionnaire. Second, it may be that expected audit fees exhibit greater variation between audit firms than other auditor characteristics, and thus will induce change more frequently.

In comparing Table 5 with Tables 2 and 4 it can be seen that in many cases auditor change is considered due to an emergent problem which affects a highly ranked auditor characteristic. For example, a high turnover of audit engagement staff has an adverse impact on the quality of working relationships with audit engagement staff. In other cases, a change in the structural characteristics of the auditee (e.g. company growth) changes the relative importance of auditor characteristics, with the incumbent no longer able to provide the required service. In a final class of cases, the structural characteristics of the auditor change (e.g. audit firm merger), with the result that the incumbent again fails to provide the service required.

\section{Conclusion}

The purpose of this paper is to contribute towards an understanding of auditor/client relationships, 
since the changing nature of these relationships, in aggregate, profoundly affects the market for audit services in the UK. Questionnaire responses from 210 listed companies are analysed to reveal fundamental aspects of the auditor choice process, such as the importance of audit firm characteristics, the reasons for changing auditor and the reasons for retaining the incumbent.

Significant within-group variation existed in companies' views on the desirability of audit firm characteristics. This variation is partially explained in terms of company size and industry group. Large companies rated several characteristics (including technical competence, quality issues and specialist industry knowledge) of significantly more importance than small companies; large companies were, however, less concerned about the absolute audit fee, perhaps because it represents a smaller proportion of operating costs for such companies. Capital goods companies rated the quality of working relationship with audit partner and common group auditor of significantly more importance than financial companies, and willingness to provide detailed cost information of more importance than consumer goods companies. Financial companies, not surprisingly, rated specialist industry knowledge of more importance than the other three industrial groups.

Factor analysis revealed eight uncorrelated audit firm dimensions of importance to companiesthe top four being reputation/quality, acceptability to third parties, value for money and ability to provide non-audit services. The nature of the much discussed 'Big Six factor' is partially revealed by our findings. This factor is itself multidimensional, encompassing, in particular, reputation/quality, acceptability to third parties and specialist industry knowledge. This provides empirical support for the quality, credibility and specialist knowledge arguments of DeAngelo (1981b), Dopuch and Simunic (1980 and 1982) and Simunic and Stein (1986) respectively.

Although the absolute level of audit fee was not ranked as an important audit firm characteristic over the sample as a whole, audit fees were the principal cause of consideration of auditor change. The 45 respondents who cited 'level of audit fee' as the most important reason for auditor change also tended to rate 'low absolute level of audit fee' as important. Changes in the structure of the audit firm, changes in the personnel of the audit team and top management changes within the auditee were also common destabilising influences. These changes principally include audit firm merger, change in audit partner (which is recommended in the Cadbury Code of Best Practice (1992)) and turnover of audit staff. Moreover, two-thirds of all companies have, to a greater or lesser degree, considered changing their auditors recently. This may be taken as an indication of underlying instability in auditor/client relationships. Of those who considered change, but did not actually change, fee reduction by the incumbent was the most frequently cited reason for retaining the status quo.

This paper has two main limitations which are suggestive of further research. First, it must be emphasised that we have investigated the reasons for the consideration of auditor change and not the reasons for actual changes. Both issues are of interest in their own right, with the former permitting inferences about the latter. The number of respondents within our sample who actually changed auditors is quite low $(n=36)$, and does not permit meaningful analysis. ${ }^{12}$ Second, this paper is based on the analysis of declared responses, collected by means of a postal questionnaire. Corroboration of these results using publicly available secondary data is desirable.

\section{References}

Albrecht, W. D. and Lamy, R. E. (1992), 'The Determinants of the Market Reaction to an Announcement of a Change in Auditor', AAA conference paper.

Bar-Yosef, S. and Livnat, J. (1984), 'Auditor Selection: An Incentive-Signalling Approach', Accounting and Business Research, Autumn, pp. 301-309.

Beattie, V. A. and Fearnley, S. (1994), 'The Changing Structure of the Market for Audit Services in the UK-A Descriptive Study', British Accounting Review, December, pp. 30l-322. Bedingfield, J. P. and Loeb, S. E. (1974), Auditor ChangesAn Examination', Journal of Accountancy, March, pp. 66-69. Burton, J. C. and Roberts, W. (1967), 'A Study of Auditor Changes', Journal of Accountancy, April, pp. 31-36.

Cadbury Report (1992), The Financial Aspects of Corporate Governance (Gee \& Co.).

Carpenter, C. G. and Strawser, R. H. (1971), 'Displacement of Auditors When Clients Go Public', Journal of Accountancy, June, pp. 55-58.

Chow, C. W. and Rice, S. J. (1982), 'Qualified Audit Opinions and Auditor Switching', Accounting Review, April, pp. 326335 .

Citron, D. B. and Taffler, R. J. (1992), 'The Audit Report under Going Concern Uncertainties: An Empirical Analysis", Accounting and Business Research, Vol. 22(88), pp. 337-345.

Craswell, A. T. (1988), 'The Association Between Qualified Opinions and Auditor Switches', Accounting and Business Research, Winter, pp. 23-31.

Davison, A. G., Stening, B. W. and Wai, W. T. (1984), 'Auditor Concentration and the Impact of Interlocking Directorates', Journal of Accounting Research, Spring, pp. 313-317.

DeAngelo, L. E. (198la), 'Auditor Independence, "Low Balling", and Disclosure Regulation", Journal of Accounting and Economics, Vol. 3, pp. 113-127.

DeAngelo, L. E. (1981b), 'Auditor Size and Audit Quality', Journal of Accounting and Economics, December. pp. 183-199.

DeAngelo, L. E. (1982), 'Mandated Successful Efforts and Auditor Choice', Journal of Accounting and Economics, Vol. 4, pp. 171-203.

DeBerg, C. L., Kaplan, S. E. and Pany, K. (1991), 'An Examination of Some Relationships Between Non-Audit Services and Auditor Change', Accounting Horizons, March, pp. $17-28$.

12This sample size is extended in a follow-up study which focuses on actual changers 
Dopuch, N. and Simunic, D. (1980), 'The Nature of Competition in the Auditing Profession: A Descriptive and Normative View', in Buckley, J. W. and Weston, J. F. (eds.), Regulation and the Accounting Profession (Lifetime Learning Publications).

Dopuch, N. and Simunic, D. (1982), 'Competition in Auditing: An Assessment', Fourth Symposium on Auditing Research (University of Illinois).

Dye, R. A. (1991), 'Informationally Motivated Auditor Replacement', Journal of Accounting and Economics, Vol. 14, pp. 347-374.

Eichenseher, J. W. (1985), 'The Effects of Foreign Operations on Domestic Auditor Selection', Journal of Accounting, Auditing and Finance, Vol. 8(3), pp. 195-209.

Eichenseher, J. W., Hagigi, M. and Shields, D. (1989), 'Market Reaction to Auditor Changes by OTC Companies', Auditing: A Journal of Practice and Theory, Fall, pp. 29-40.

Eichenseher, J. W. and Shields, D. (1983), 'The Correlates of CPA-Firm Change of Publicly-Held Corporations', Auditing: A Journal of Practice and Theory, Spring, pp. 2337.

Ettredge, M. and Greenberg, R. (1990), 'Determinants of Fee Cutting on Initial Audit Engagements', Journal of Accounting Research, Vol. 28(1), Spring, pp. 198-210.

Firth, M. and Smith, A. (1992), 'Selection of Auditor Firms by Companies in the New Issue Market', Applied Economics, Vol. 24, pp. 247-255.

Fitzgerald, N. (1992), 'Survey Findings: Putting a Priority on Clarity', CA Magazine, November, pp. 24-33.

Francis, J. (1984), 'The Effect of Audit Firm Size on Audit Prices: A Study of the Australian Market', Journal of Accounting and Economics, Vol. 6, pp. 133-151.

Francis, J. R. and Wilson, E. R. (1988), 'Auditor Changes: A Joint Test of Theories Relating to Agency Costs and Auditor Differentiation', Accounting Review, October, pp. 663-682.

Fried, D. and Schiff, A. (1981), 'CPA Switches and Associated Market Reactions', Accounting Review, April, pp. 324-341.

Haskins, M. E. and Williams, D. D. (1990), 'A Contingent Model of Intra-Big Eight Auditor Changes', Auditing: A Journal of Practice and Theory, Fall, pp. 55-74.

Healy, P. and Lys, T. (1986), 'Auditor Changes Following Big Eight Mergers with Non-Big Eight Audit Firms', Journal of Accounting and Public Policy, Vol. 5, pp. 251-265.

Jensen, M. and Meckling, W. (1976), 'Theory of the Firm: Managerial Behaviour, Agency Costs and Ownership Structure', Journal of Financial Economics, October, pp. 305360 .

Johnson, W. B. and Lys, T. (1990), 'The Market for Audit Services: Evidence from Voluntary Auditor Changes', Journal of Accounting and Economics, Vol. 12, pp. 281308.

Kaplan, S. E., Menon, K. and Williams, D. D. (1990), 'The Effect of Audit Structure on the Audit Market', Journal of Accounting and Public Policy, Vol. 9, pp. 197-215.

Kim, J.-O. and Mueller, C. W. (1978), Introduction to Factor Analysis: What It Is and How To Do It (Sage Publications)
Krishnan, J. (1992), 'An Empirical Model of Opinion Shopping Behaviour' (AAA conference paper).

Levinthal, D. A. and Fichman, M. (1988), 'Dynamics of Interorganizational Attachments: Auditor-Client Relationships', Administrative Science Quarterly, Vol. 33, pp. 345-369.

Lindahl, F. W. (1992), 'How Much Do We Know About Auditor Changes? The Effect of Observed and Unobserved Heterogeneity' (AAA conference paper).

Lynn, S. A. (1987), 'Segmenting the CPA Services Market', Advances in Accounting, Vol. 4, pp. 239-265.

Menon, K. and Williams, D. D. (1991), 'Auditor Credibility and Initial Public Offerings', Accounting Review, April, pp. 313-332.

Nichols, D. R. and Smith, D. B. (1983), 'Auditor Credibility and Auditor Changes', Journal of Accounting Research, Autumn, pp. 534-544.

Oppenheim, A. N. (1966), Questionnaire Design and Attitude Measurement (Heinemann).

SAS (1990), SAS/STAT User's Guide Volume 1, 4th edition (SAS Institute, Cary, NC)

Schwartz, K. B. and Menon, K. (1985), 'Auditor Switches by Failing Firms', Accounting Review', April, pp. 248-261.

Siegel, S. and Castellan, N. J. (1988), Non-parametric Statistics for the Behavioural Sciences (McGraw-Hill).

Simon, D. T. and Francis, J. R. (1988), 'The Effects of Auditor Change on Audit Fees: Tests of Price Cutting and Price Recovery', Accounting Review, April, pp. 255-269.

Simunic, D. A. and Stein, M. (1986), 'On the Economics of Product Differentiation in Auditing', in Proceedings of the 1986 Touche Ross/University of Kansas Symposium on Auditing Problems, pp. 69-99.

Smith, D. B. (1986), "Auditor "Subject To" Opinions, Disclaimers, and Auditor Changes', Auditing: A Journal of Practice and Theory, Fall, pp. 95-108.

Smith, D. B. (1988), 'An Investigation of Securities and Exchange Commission Regulation of Auditor Change Disclosures: The Case of Accounting Series Release No. 165, Journal of Accounting Research, Spring, pp. 134-145.

Stokes, D. (1992), 'The Market for Audit Services: Evidence from Audit Firm Mergers' (AAA conference paper).

Titman, S. and Trueman, B. (1986), 'Information Quality and the Valuation of New Issues', Journal of Accounting and Economics, Vol. 8, pp. 159-172.

Wallace, W. A. (1980), 'The Economic Role of the Audit in Free and Regulated Markets", The Touche Ross and Co. Aid to Education Program, reprinted in Auditing Monographs (Macmillan Publishing Co., 1985).

Wallace, W. A. (1987), 'The Economic Role of the Audit in Free and Regulated Markets: A Review', Research in Accounting Regulation, Vol. 1, pp. 7-34.

Wallace, R. S. O. and Mellor, C. J. (1988), 'Non-response Bias in Mail Accounting Surveys: A Pedagogical Note', British Accounting Review, August, pp. 131-139.

Williams, D. D. (1988), 'The Potential Determinants of Auditor Change', Journal of Business Finance and Accounting, Summer, pp. 243-261. 
Copyright of Accounting \& Business Research is the property of Croner.CCH Group Limited and its content may not be copied or emailed to multiple sites or posted to a listserv without the copyright holder's express written permission. However, users may print, download, or email articles for individual use. 